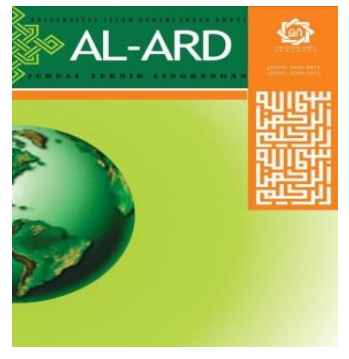

Al-Ard: Jurnal Teknik Lingkungan

Vol.6 No.1 - September 2020 (hal. 37-43)

http://jurnalsaintek.uinsby.ac.id/index.php/alard/index
Al-Ard:

Jurnal

Teknik Lingkungan

\title{
Upaya Penurunan Nilai COD pada Limbah Tekstil dan Batik dengan Penambahan NaOCl \\ Linda Aliffia Yoshi ${ }^{1}$, Jessica Ambarwati Idat ${ }^{2}$, Galuh Maulidyananda ${ }^{3}$, Ratnawati ${ }^{4}$ \\ 1,2,3,4 Institut Teknologi Indonesia, Tangerang Selatan, Indonesia \\ linda.aliffia@iti.ac.id ${ }^{1}$
}

\begin{abstract}
Batik and textile production produces liquid waste with a COD content above the environmental quality standard between 2,000-12,000 ppm. Efforts to reduce the value of COD are helped by the addition of NaOCl. This study aims to determine the $\mathrm{pH}$ and dose of $\mathrm{NaOCl}$ against $\mathrm{COD}$ reduction. Textile liquid waste used came from factory $\mathrm{X}$ while batik liquid waste came from factory $\mathrm{Y}$; both factories are located in South Tangerang. In this study, the pH range, 5, 7, and 9 and $\mathrm{NaOCl}$ concentrations were added in 3000, 4000, and $5000 \mathrm{ppm}$. The study begins with the measurement of the actual COD value in the two wastewater. The best results for batik waste were obtained at pH 5 with the addition of $4000 \mathrm{ppm} \mathrm{NaOCl}$ which resulted in a decrease of $93 \%$. Textile liquid waste shows the best results at pH 5 with an additional 5000 ppm NaOCl concentration which can reduce COD by $95 \%$. However, the $\mathrm{pH}$ has not met standart required, 6-9, so post treatment is needed to adjusment $\mathrm{pH}$. pH 5 is the $\mathrm{pH}$ process. The final result of the COD value has met the quality standard set by the government in Yogyakarta which is less than $250 \mathrm{ppm}$.
\end{abstract}

Keywords: Batik waste, textile waste, $\mathrm{COD}, \mathrm{NaOCl}$

\begin{abstract}
Abstrak
Produksi batik dan tekstil menghasilkan limbah cair dengan kandungan COD di atas baku mutu lingkungan hidup antara 2.000-12.000 ppm. Upaya untuk menurunkan nilai COD dibantu dengan penambahan $\mathrm{NaOCl}$. Penelitian ini bertujuan menentukan $\mathrm{pH}$ proses dan dosis $\mathrm{NaOCl}$ terhadap penurunan COD. Limbah cair tekstil yang digunakan berasal dari pabrik X sedangkan limbah cair batik berasal dari pabrik Y; kedua pabrik berlokasi di Tangerang Selatan. Pada penelitian ini digunakan ragam pH, yaitu 5, 7, dan 9 serta konsentrasi $\mathrm{NaOCl}$ yang ditambahkan 3000, 4000, dan 5000 ppm. Penelitian diawali dengan pengukuran nilai COD yang sebenarnya pada kedua limbah cair tersebut. Hasil terbaik untuk limbah batik didapatkan pada pH 5 dengan penambahan $\mathrm{NaOCl} 4000$ ppm yang menghasilkan penurunan sebesar 93\%. Untuk limbah cair tekstil menunjukkan hasil terbaik pada pH 5 dengan tambahan konsentrasi $\mathrm{NaOCl} 5000$ ppm yang dapat menurunkan COD sebesar 95\%. Meskipun demikian, pH belum memenuhi standar yang disyaratkan yaitu 6-9 sehingga diperlukan post treatmen $\mathrm{pH}$ sebab $\mathrm{pH} 5$ merupakan $\mathrm{pH}$ proses. Hasil akhir nilai COD sudah memenuhi aturan baku mutu yang ditetapkan pemerintah Yogayakarta yaitu kurang dari 250 ppm.

Kata Kunci: Limbah batik, limbah tekstil, COD, NaOCl
\end{abstract}

\section{PENDAHULUAN}

Indonesia,

khususnya Daerah Istimewa Yogyakrta merupakan daerah yang kaya akan keanekaragaman budaya dan seni kerajinannya, salah satu seni kerajinan yang terkenal hingga mancanegara adalah batik yang berasal dari industri tekstil. Industri tekstil mengalami kenaikan setiap tahunnya sebesar $0.85 \%$ (Muljadi, 2009), serta menurut survei Kementrian Perindustrian padatahun 2010, diketahui jumlah konsumen batik tercatat 72.86 juta orang dan diekspor hingga keluar negeri. Seiring dengan menjamurnya industri tekstil dan batik menyebabkan bertambahnya limbah cair yang dihasilkan. Limbah ini merupakan salah satu pencemar di badan sungai sebab limbah cair yang dihasilkan dari industri batik dan tekstil merupakan limbah yang mengandung senyawa logam (krom, timbal, nikel, tembaga, dan mangan) yang tidak mudah diuraikan oleh mikroorganisme secara alamiah (Endrinaldi, 2010). Senyawa tersebut berpotensi menimbulkan gangguan kualitas air, salah satunya tingginya nilai COD (Chemical Oxygen Demand). Dimana, COD ini merupakan salah kunci parameter untuk mendeteksi tingkat pencemaran air. Semakin tinggi COD maka, 
maka akan semakin buruk kualitas air yang ada (Estikarini dkk, 2016).

COD adalah jumlah oksigen yang diperlukan agar bahan buangan yang terdapat dalam perairan dapat teroksidasi melalui reaksi kimia. Berdasarkan Peraturan Gubernur Yogyakarta Nomor 7 tahun 2016, bahwa baku mutu limbah cair untuk industri batik dan tekstil, nilai COD yang dibuang ke bdan lingkunga tidak boleh melebihi $250 \mathrm{ppm}$. Namun kenyataannya, kandungan nilai COD limbah tekstil berkisar antara 2000-12,000 ppm (Estikarini dkk, 2016) dan limbah batik sebesar 4230 ppm (Agustina dkk, 2011). Nilai COD yang masih melebihi batas baku mutu diperlukan upaya untuk menurunkannya.

Secara umum, penurunan COD limbah cair dapat dilakukan dengan tiga cara yaitu fisika, kimia, biologis dan bahkan kombinasi diantara 3 proses tersebut. Pada dasarnya proses kimiawi lebih dipilih dibandingkan proses lainnya karena lebih cepat dan biaya investasi lebih rendah. Oksidator diperlukan untuk mengoksidasi kontaminan yang ada didalam limbah, salah satunya adalah $\mathrm{NaOCl}$. Kelebihan $\mathrm{NaOCl}$ proses yang mudah dilakukan dan pengontrolan, serta murah dan mudah didapatkan. Saat $\mathrm{NaOCl}$ bereaksi dengan air membentuk ion $\mathrm{HOCl}$ yang akan mengoksidasi bahan organik yang ada di limbah dengan kadar yang tepat, sebab apabila melebihi jumlah yang semestinya akan menyebabkan akumulasi senyawa klor. Klor di air limbah mereduksi beberapa zat kimia yang menyebabkan turunnya nilai DO. Tingkat keasaman $(\mathrm{pH})$ juga harus diperhatikan karena menentukan seberapa banyak ion HOCl yang terbentuk.

Aplikasi $\mathrm{NaOCl}$ untuk menurunkan COD diantaranya untuk mengolah limbah VCM pada $\mathrm{pH} 5$, konsentrasi 40-50 gr/jam, memberikan hasil penurunan 82 dan $88 \%$ (Ratnawati dkk, 2017). Salah satu industri di Iran, berhasil menurunkan COD sebesar $84 \%$ (Behin, Akbari dkk, 2017), limbah tannery sebesar 76\% (kadar awal 3413 ppm (Awan dan Ali, 2004), dan juga Common Effluent Treatment Plants (CETPS) di India turun sebesar $68.57 \%$ dengan waktu retensi 1 jam, konsentrasi $\mathrm{NaOCl} 200 \mathrm{ppm}$ (Lalwani dan Devadasan, 2013). Oleh karena itu, penelitian ini bertujuan untuk menentukan $\mathrm{pH}$ proses dan konsentrasi $\mathrm{NaOCl}$ terbaik terhadap penurunan COD yang terkandung pada limbah tekstil dan limbah batik untuk dapat memenuhi baku mutu lingkungan.

\section{METODE PENELITIAN 2.1 Bahan}

Bahan baku menggunakan limbah tekstil dan batik yang diambil dari salah satu industri di daerah Tangerang Selatan. Pengukuran kadar COD dilakukan sebelum dan sesudah penambahan $\mathrm{NaOCl}$. Spesifikasi bahan baku disajikan pada Tabel 1 sedangkan bahan kimia yang digunakan tersaji pada Tabel 2.

\begin{tabular}{|c|c|c|}
\hline Sampel & \multicolumn{2}{|r|}{ Spesifikasi } \\
\hline \multirow{4}{*}{ Limbah Batik } & Kadar COD & $2449.91 \mathrm{ppm}$ \\
\hline & & 7 \\
\hline & Warna & Hijau \\
\hline & Suhu & $30^{\circ} \mathrm{C}$ \\
\hline Limbah & Kadar COD & $4209.1 \mathrm{ppm}$ \\
\hline \multirow{3}{*}{ Tekstil } & $\mathrm{pH}$ & 12 \\
\hline & Warna & Coklat \\
\hline & Suhu & $30^{\circ} \mathrm{C}$ \\
\hline \multicolumn{3}{|c|}{ Tabel 2. Daftar Bahan } \\
\hline Bahan & Spesifikasi & Fungsi \\
\hline $\mathrm{NaOCl}$ & Liquid, $12 \%$ & oksidator \\
\hline $\mathrm{K}_{2} \mathrm{Cr}_{2} \mathrm{O}_{7}$ & Solid, $99.9 \%$ & $\begin{array}{l}\text { Bahan pembuat deret } \\
\text { standart klor }\end{array}$ \\
\hline $\mathrm{C}_{8} \mathrm{H}_{5} \mathrm{KO}_{4}$ & Solid, analitis & $\begin{array}{l}\text { Larutan standart kurva } \\
\text { kalibrasi }\end{array}$ \\
\hline $\mathrm{NaOH}$ & Solid, 98\% & Pengaturan $\mathrm{pH}$ basa \\
\hline $\mathrm{HCl}$ & Liquid, 36\% & Pengaturan $\mathrm{pH}$ asam \\
\hline $\mathrm{H}_{2} \mathrm{SO}_{4}$ & Liquid, 98\% & Katalis \\
\hline $\mathrm{HgSO}_{4}$ & Solid & $\begin{array}{l}\text { Penghilang gangguan } \\
\text { klorida }\end{array}$ \\
\hline Aquadest & Liquid & $\begin{array}{l}\text { Membuat larutan, } \\
\text { pengenceran }\end{array}$ \\
\hline
\end{tabular}

\subsection{Prosedur dan Analisa}

Sebelum dan sesudah penelitian, COD diukur pada setiap variasi $\mathrm{pH}$ dan konsentrasi $\mathrm{NaOCl}$ dengan kondisi operasi $150^{\circ} \mathrm{C}$ dan 30 menit. Analisi kadar COD mengacu pada SNI 6989.73:2009. Pengukuran kadar COD menggunakan alat spektrofotemetri yang sebelumnya telah dilakukan proses oksidasi.

\section{Proses Oksidasi}

Proses oksidasi merupakan proses untuk mengoksidasi kandungan organik yang ada didalam limbah, proses oksidasi menggunakan tabung ampul berukuran standar $10 \mathrm{ml}$.

\section{Membuat Larutan Induk}

Larutan induk merupakan larutan standar yang memiliki nilaikonsentrasi tertinggi yakni larutan standar konsentrasi 1000 ppm, adapun Kalium Hidrogen Ftalat ( $\mathrm{HOOCC}{ }_{6} \mathrm{H}_{4} \mathrm{COOK}$, KHP) yang digunakan sebagai larutan standar. KHP ditimbangkan sebanyak 0.25 gram kemudian dilarutkan ke dalam $250 \mathrm{ml}$ aquadest. 


\section{Membuat Larutan Baku}

Larutan baku adalah larutan yang dibuat dari larutan induk yang diencerkan menggunakan air suling bebas organik sampai kadar tertentu. Dalam penelitian ini, larutan baku dibuat dengan variasi konsentrasi sebagai berikut : $1000 ; 900 ; 800 ; 700 ; 600$; $500 ; 400 ; 300 ; 200 ; 100 ; 50 ; 0$ ppm.

Langkah kerja disajikan pada Gambar 1.

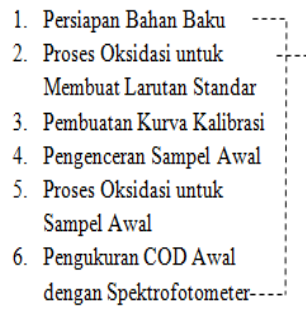

Persiapan Bahan Baku

Proses Oksidasi untuk

Pembuatan Kurva Kalibrasi

Pengenceran Sampel Awa

Sampel Awal

dengan Spektrofotometer--

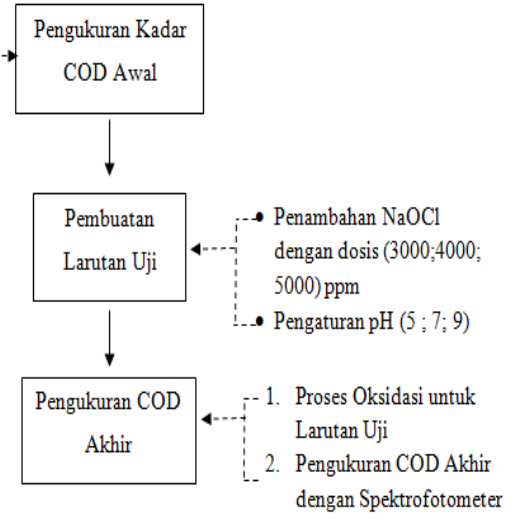

Gambar 1. Tahapan Penelitian

Perhitungan penurunan konsentrasi COD menggunakan rumus:

$\%$ penurunan $=\frac{\text { COD awal }- \text { COD akhir }}{\text { COD awal }} \times 100 \%$

\section{HASIL DAN PEMBAHASAN}

\subsection{Kurva kalibrasi}

Hasil pengujian deret larutan kerja pada spektofotometer, variasi konsentrasi 0-1000 ppm (perbedaan 100 ppm) ditunjukkan pada Gambar 2.

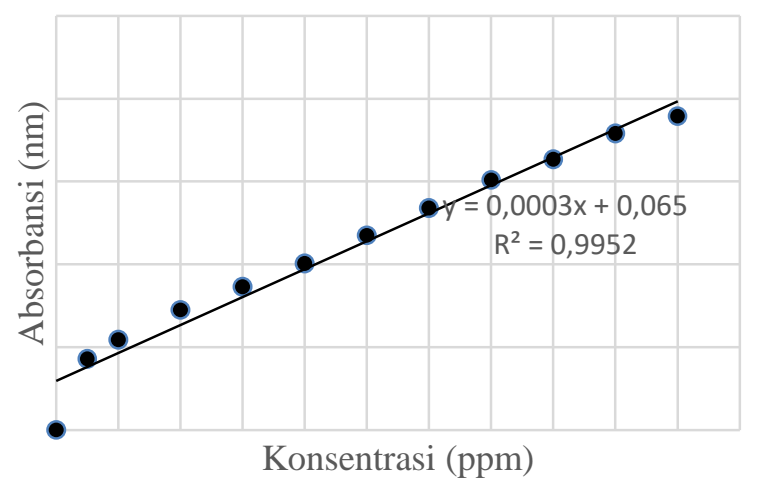

Gambar 2. Kurva Kalibrasi Larutan Standart

Gambar tersebut menyatakan kurva kalibrasi merupakan hubungan antara konsentrasi standar atau larutan kerja variasi 0 ; 50; 100; 200; 300; 400; 500; 600; 700; 800; 900; dan 1000 ppm dengan respon instrument yang dinyatakan dalam grafik garis lurus, yang diukur pada panjang gelombang maksimal $597.8 \mathrm{~nm}$. Panjang gelombang ini memiliki spesifikasi warna yang terserap adalah jingga sedangkan warna yang terlihat adalah biru kehijauan.

Diketahui nilai koefisien korelasi kurva kalibrasi sebesar 0.9997, dengan persamaan garis $\mathrm{y}=0.0003 \mathrm{x}+0.065$. Berdasarkan SNI 6989.2:2009, batas keberterimaan koefisien regresi linear sebesar $(\mathrm{r}) \geq 0.995$ atau koefisien determinasi sebesar $\left(\mathrm{R}^{2}\right) \geq 0.995$, hal ini menandakan, kurva kalibrasi larutan kerja telah memenuhi syarat keberterimaan. Senyawa hidrogen ftalat dianggap mewakili senyawa organik dalam larutan yang dioksidasi oleh larutan kalium dikromat melalui reaksi berikut:

$$
\mathrm{C}_{8} \mathrm{H}_{5} \mathrm{O}_{4}^{-}+5 \mathrm{Cr}_{2} \mathrm{O}_{7}^{2-}+41 \mathrm{H}^{+} \rightarrow 8 \mathrm{CO}_{2}+23 \mathrm{H}_{2} \mathrm{O}+10 \mathrm{Cr}^{3+}
$$

\subsection{Data Pengamatan} Tabel 3.

Data hasil pengujian larutan tersaji pada Tabel 3. Data Pengamatan Penurunan Konsentrasi COD pada Limbah Batik dan Limbah Tekstil

\begin{tabular}{|c|c|c|c|c|c|}
\hline $\mathrm{A}$ & B & $\mathrm{C}$ & $\mathrm{D}$ & $\mathrm{E}$ & $\mathrm{F}$ \\
\hline \multirow{9}{*}{ Batik } & \multirow{9}{*}{2449.9} & \multirow{3}{*}{3000} & 5 & 322.96 & 86.82 \\
\hline & & & 7 & 843.42 & 65.57 \\
\hline & & & 9 & 1127.12 & 53.99 \\
\hline & & \multirow{3}{*}{4000} & 5 & 186.74 & 92.38 \\
\hline & & & 7 & 588.08 & 75.99 \\
\hline & & & 9 & 920.70 & 62.42 \\
\hline & & \multirow{3}{*}{5000} & 5 & 171.33 & 93.01 \\
\hline & & & 7 & 405.87 & 83.43 \\
\hline & & & 9 & 416.88 & 82.98 \\
\hline \multirow{9}{*}{ Tekstil } & \multirow{9}{*}{4209.1} & \multirow{3}{*}{3000} & 5 & 558.26 & 86.74 \\
\hline & & & 7 & 851.00 & 79.78 \\
\hline & & & 9 & 882.31 & 79.04 \\
\hline & & \multirow{3}{*}{4000} & 5 & 536.23 & 87.26 \\
\hline & & & 7 & 818.72 & 80.55 \\
\hline & & & 9 & 877.42 & 79.15 \\
\hline & & \multirow{3}{*}{5000} & 5 & 207.28 & 95.08 \\
\hline & & & 7 & 547.73 & 86.99 \\
\hline & & & 9 & 786.43 & 81.32 \\
\hline
\end{tabular}

Keterangan :

A : Jenis Limbah

B : Kadar COD awal (ppm) 


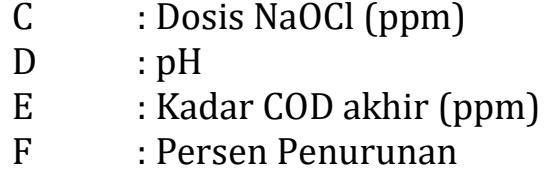

\subsection{Pengaruh $\mathrm{pH}$ dan dosis NaOCl pada penurunan kadar COD pada limbah batik}

$\mathrm{NaOCl}$ merupakan oksidator kuat yang dapat mengoksidasi zat organik di limbah batik seperti natrium, zat warna, amilum dari proses pengkanjian. Selain itu juga merupakan desinfektan yang dapat mengurai senyawa kimia dengan cara mengoksidasi. Pengoksidasian tersebut yang akan mengakibatkan terjadinya penurunan nilai COD pada limbah cair (Ratnawati dkk, 2017).

Reaksi yang terjadi adalah sebagai berikut:

Reaksi $\mathrm{NaOCl}+\mathrm{H}_{2} \mathrm{O} \rightarrow \mathrm{NaOH}+\mathrm{HOCl}$

hidrolisis

Reaksi $\quad \mathrm{HOCl} \rightarrow \mathrm{HCl}+\mathrm{O}_{2}$

pelepasan

Pada persamaan reaksi (2) $\mathrm{NaOCl}$ bereaksi dengan air membentuk ion $\mathrm{HOCl}$ dalam suasana basa. Pada $\mathrm{pH}$ basa, $\mathrm{NaOCl}$ hanya dapat membentuk ion $\mathrm{HOCl}$ dalam jumlah yang sedikit serta sifatnya tidak stabil sehingga dapat terurai (persamaan reaksi 3). $\mathrm{HOCl}$ bertugas untuk mengoksidasi bahan organik. Apabila HOCl yang terbentuk sedikit, maka penurunan COD limbah tidak akan optimal. Upaya untuk membuat jumlah ion HOCl semakin banyak dengan menambahkan $\mathrm{HCl}$ kedalam air, sehingga $\mathrm{pH}$ menjadi asam. Persamaan 4 dan 5 merupakan reaksi $\mathrm{NaOCl}$ saat ditambahkan asam klorida.

Reaksi pembentukan $\mathrm{HOCl} \quad$ :

Reaksi $\mathrm{NaOCl}+\mathrm{HCl} \rightarrow \mathrm{NaCl}+\mathrm{HOCl}$

pembentukan

$\mathrm{HOCl}$

Reaksi $\quad \mathrm{HOCl}+\mathrm{HCl} \rightarrow \mathrm{H}_{2} \mathrm{O}+\mathrm{Cl}_{2}$

pembentukan

klor bebas

Adapun data pengamatan penurunan COD limbah batik apabila digambarkan dalam grafik tersaji pada Gambar 3.

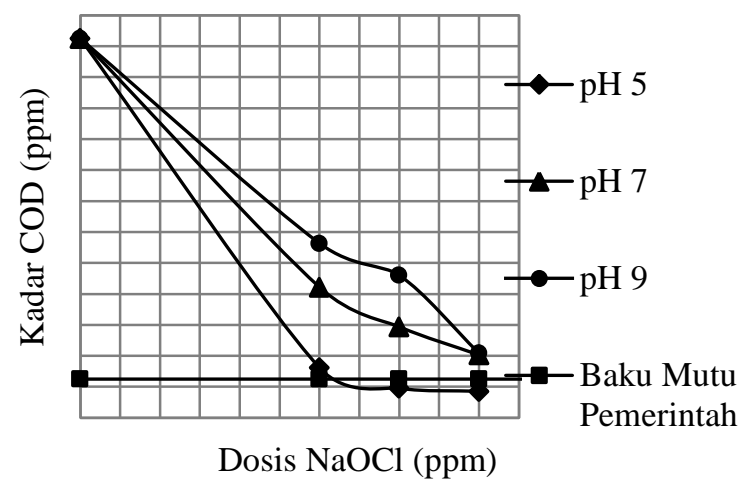

Gambar 3. Pengaruh $\mathrm{pH}$ dan Dosis $\mathrm{NaOCl}$ terhadap Penurunan COD Limbah Batik

Berdasarkan Gambar 3, terdapat 4 buah tren. Dimana, tren horizontal menunjukkan nilai keberterimaan COD yang ditetapkan pemerintah Yogyakarta yakni kurang dari $250 \mathrm{ppm}$. Dan 3 tren lainnya merupakan tren variabel $\mathrm{pH}(5 ; 7 ; 9)$, yang berpusat pada satu titik awal yakni konsentrasi COD awal limbah batik sebesar 2449.91 ppm dan kemudian menukik kebawah yang menunjukkan seberapa jauh pengaturan $\mathrm{pH}(5 ; 7 ; 9)$ serta penambahan $\mathrm{NaOCl}$ dengan dosis (3000; 4000; 5000 ppm) mampu menurunkan nilai COD di limbah.

Hasil penurunan $\mathrm{pH} 7$ dengan $\mathrm{pH} 9$ tidak begitu jauh, serta tidak menyentuh tren horizontal yang merupakan nilai keberterimaan COD. Karena menurut Rahardjo, 2012 pada pH 7 dan 9 bahkan yang semakin asam yaitu $\mathrm{pH} 2$, klor yang ada bukan sebagai $\mathrm{HOCl}$ tetapi membentuk sebagai senyawa klorida $\left(\mathrm{Cl}_{2}\right)$ dan $\mathrm{OCl}^{-}$dalam jumlah banyak sedangkan $\mathrm{HOCl}$ yang bertugas mengoksidasi senyawa organik hanya sedikit. Hal ini menyebabkan $\mathrm{Cl}_{2}$ sebagai klor bebas semakin tingi, menyebabkan penurunan kekuatan oksidasi sehingga penurunan nilai COD tidak optimal. Sementara itu, tren pH 5 cukup jauh dan melewati garis horizontal yang artinya mampu menurunkan COD sampai memenuhi baku mutu lingkungan. Pada kondisi ini, $\mathrm{NaOCl}$ mampu membentuk ion HOCl lebih banyak, reaksi berlangsung kekanan,. maka HOCl akan mengoksidasi kandungan bahan organik yang terdapat didalam limbah batik juga lebih banyak.

Dari penelitian yang sudah dilakukan sebelumnya, didapatkan bahwa $\mathrm{pH}$ asam mampu menurunkan COD limbah batik, karena akan menyebabkan reaksi (9) bergeser kekanan sehingga didapatkan senyawa $\mathrm{HOCl}$ dalam jumlah yang lebih banyak. Hal ini juga sesuai dengan beberapa penelitian yang 
melaporkan bahwa penurunan COD limbah industri penyamakan mengunakan reagen fenton, pH optimum adalah 4 (Muhammad dkk, 2013), pH 5 dapat menurunkan COD sebesar 79\% (Hartati dkk, 2008), dan pada $\mathrm{pH}$ asam dapat mengurai limbah batik 64-93\% (Laksono dan Sucipta, 2012). Begitu juga yang dilakukan oleh Tosik dkk, 2004; Rana dan Sureh, 2007; Muhammad dkk, 2008; Said, 2009; Karaouglu dan Ulurgurlu, 2010; Dhira dkk, 2012; Behin, 2017; Zou dkk, 2017 bahwa pH terbaik adalah 5.

Penambahan dosis $\mathrm{NaOCl}$ yang tepat juga mempengaruhi penurunan COD limbah batik. Hasil terbaik didapatkan pada konsentrasi NaOCl 5000 ppm menjadi 171.33 ppm atau sebesar 93\%. Akan tetapi konsentrasi $\mathrm{NaOCl} 4000 \mathrm{ppm}$ sudah mampu menurunkan COD sebesar 93\% dengan nilai akhir 186.74 ppm. Oleh karena itu pada kondisi ini, jumlah $\mathrm{NaOCl}$ yang ditambahkan sudah sesuai stokiometri reaksi oksidasi senyawa organik dengan $\mathrm{HOCl}$.

Asam hipoklorit (HOCl) dapat terbentuk selama hidrolisa seperti persamaan reaksi 7 sedangkan persamaan 8 terjadi reaksi pelepasan atom oksigen karena asam yang terbentuk selama reaksi hidrolisa tidak stabil dan mudah terurai selama $\mathrm{HOCl}$ yang dibutuhkan tercukupi, proses degradasi tetap akan berjalan meskipun konsentrasi $\mathrm{NaOCl}$ tidak terlalu tinggi (Ratnawati dkk, 2017).

\subsection{Pengaruh pH proses dan dosis $\mathrm{NaOCl}$ terhadap penurunan kadar COD pada limbah tekstil}

Kandungan yang terdapat dalam limbah tekstil adalah zat warna sisa yang berasal dari proses pewarnaan. Zat warna ini mengandung senyawa azo sehingga reaksi antara zat warna dengan $\mathrm{NaOCl}$ :

$$
\text { Zat warna }+\mathrm{HOCl} \rightarrow \mathrm{CO}_{2}+\mathrm{H}_{2} \mathrm{O}+\mathrm{Cl}_{2}+\mathrm{P}
$$

Dapat dilihat pada Gambar 4, bahwa garis menukik kebawah pada tren $\mathrm{pH} 7$ dan 9 berdempetan pada penambahan $\mathrm{NaOCl}$ dosis $3000 \mathrm{ppm}$, hal ini mengindikasikan bahwa banyaknya ion klor $\mathrm{OCl}^{-}$dan $\mathrm{Cl}_{2}$ dalam jumlah yang sama, sehingga penurunan COD nya bernilai sama. Selanjutnya kedua tren ini mengambil jarak, dimana pH 7 menukik kebawah dan mengambil jarak dengan $\mathrm{pH}$ 9, hal ini menunjukkan pH 7 melakukan penurunan COD yang lebih banyak dibandingkan dengan $\mathrm{pH}$ 9. Hal tersebut dikarenakan jumlah ion klor berupa $\mathrm{HOCl}$ yang terbentuk dalam suasana basa dihasilkan dalam jumlah yang sedikit, sehingga $\mathrm{HOCl}$ yang mampu mengoksidasi sedikit bahan organik di dalam limbah tekstil tidak optimal.

Apabila pH air lebih dari 8.5, maka $90 \%$ dari asam hipoklorit itu akan mengalami ionisasi menjadi ion hipoklorit sehingga khasiat yang dimiliki klorin akan menjadi lemah atau kurang untuk mengoksidasi senyawa organik (Andhika dkk, 2013). Oleh karena itu, tren pH 7 dan 9 belum mampu mencapai garis horizontal yang merupakan nilai keberterimaan COD yang ditetapkan oleh pemerintah, yang artinya pada variasi $\mathrm{pH} 7$ dan 9 belum memenuhi baku mutu.

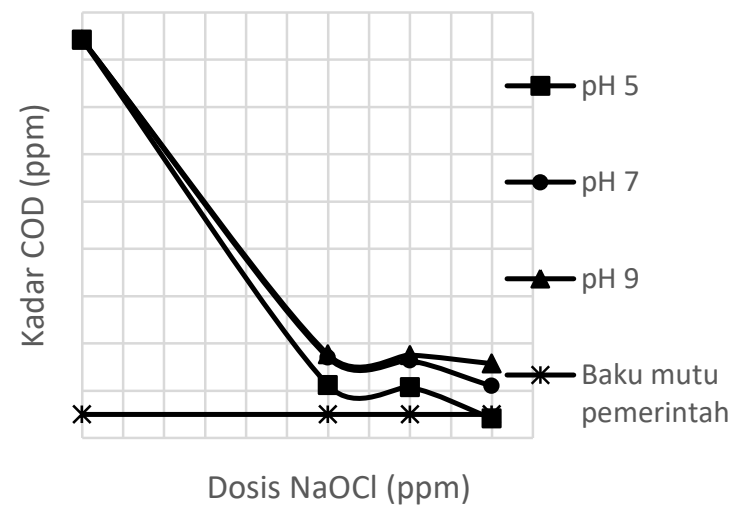

Gambar 4. Pengaruh $\mathrm{pH}$ dan Dosis NaOCl terhadap Penurunan COD Limbah Tekstil

Berdasarkan data pengamatan, didapatkan bahwa tren pH 5 merupakan satusatunya tren yang mampu menyentuh garis horizontal, yang artinya pada pH 5 merupakan kondisi $\mathrm{pH}$ yang mampu mendukung penurunan COD sampai memenuhi baku mutu. Hal tersebut dikarenakan pada $\mathrm{pH}$ asam, ion klor bekerja dalam bentuk asam hipoklorit (HOCl) dan sebagian kecil dalam bentuk ion hipoklorit $\left(\mathrm{OCl}^{-}\right)$, sehingga $\mathrm{HOCl}$ mampu mengoksidasi bahan organik dalam jumlah yang banyak pula hingga memenuhi baku mutu yang ditetapkan oleh pemerintah. Klor bekerja dalam bentuk asam hipoklorit $(\mathrm{HOCl})$ dan sebagian kecil dalam bentuk ion hipoklorit ( $\left.\mathrm{OCl}^{-}\right)$. Seperti halnya yang dilakukan oleh Tuani Lidiawati S., dkk (2015) pada pengolahan limbah tekstil menggunakan elektrokoagulasi didapatkan $\mathrm{pH}$ optimum adalah 5 dengan presentase penurunannya sampai 95\%. Penelitian Ratnawati, dkk (2017) didapatkan bahwa $\mathrm{pH}$ optimum untuk menurunkan COD pada limbah vinil klorida yaitu pada $\mathrm{pH} 5$. 
Hasil terbaik yang didapatkan pada kondisi $\mathrm{pH}$ optimum dengan penambahan $\mathrm{NaOCl}$ dengan dosis 5000 ppm yang berhasil menurunkan COD sampai 207.28 ppm dari kandungan awal COD sebesar 4209.1 ppm, yang mempunyai persentase penurunan COD sebesar 95.075\%. Berdasarkan hal tersebut, didapatkan bahwa diperlukan penambahan $\mathrm{NaOCl}$ dengan dosis yang lebih banyak untuk menurunkan COD limbah tesktil daripada limbah batik untuk menurunkan COD sampai pada baku mutu pemerinta. Hal tersebut dikarenakan kandungan COD awal limbah tekstil mengandung zat organik yang lebih banyak, yang ditunjukkan oleh besarnya nilai COD awal tekstil yakni sebesar $4209.1 \mathrm{ppm}$. Jika dibandingkan dengan limbah batik yang mengandung COD awal sebesar 2449.91 ppm, yang hanya memerlukan penambahan $\mathrm{NaOCl}$ dengan dosis 4000 ppm sampai memenuhi baku mutu. Selain itu, kadar COD limbah tekstil lebih besar daripada limbah batik sehingga dapat dinyatakan bahwa lebih banyak oksigen yang dibutuhkan untuk mengoksidasi senyawa organik pada limbah tekstil dibandingkan dengan limbah batik.

\section{KESIMPULAN}

Limbah tekstil dan batik yang kandungan COD di atas peraturan pemerintah dapat diturunkan dengan ditambahkan $\mathrm{NaOCl}$ dan ditentukan $\mathrm{pH}$ proses terbaik. Penelitian ini mendapatkan hasil bahwa dengan ditambahkan $\mathrm{NaOCl}$ kosentrasi 4000 ppm dan $\mathrm{pH}$ proses 5, dapat menurunkan COD $92 \%$ (limbah batik) sedangkan untuk limbah tekstil konsentrasi 5000 ppm dengan $\mathrm{pH}$ proses 5, dapat menurunkan hingga 95\% sehingga konsentrasi COD kedua limbah tersebut sudah memenuhi baku mutu yang ditetapkan pemerintah yaitu kurang dari 250 ppm. Meskipun demikian jika dibuang ke badan lingkungan maka harus ada post treatment untuk adjusment nilai $\mathrm{pH}$ seperti yang di syaratkan yaitu antara 6-9.

\section{DAFTAR PUSTAKA}

Agustina, Nurisman, Prasetyowati, \& Haryani. (2011). Pengolahan Air Limbah Pewarna Sintesis dengan Menggunakan Reagen Fenton. Prosiding Seminar Nasional ke-3 ISBN: 979-587-395-4. Palembang: Fakultas Teknik Universits Sriwijaya.
Awan, \& Ali, M. (2004). Reduction of chemical oxygend demand from Tannery wastewater by oxidation. Electronic Journal of Environmental, Agricultural and Food Chemistry, 3 (I), 625-628.

Azbar, Yonar, \& Kestioglu. (2004). Comparison of Various Advanced Oxidation Processes And Chemical Treatment Methods for COD and Colour Removal From Polyester and Acetate Fiber Dying Effluent. Chemosphere, 55, 8186.

Behin, J., Akbari, A., Mahmoudi, M., \& Khajeh, M. (2017). Sodium hypochlorite as an alternative to hydrogen peroxide in fenton process for industrial scale. Water Research, (121):120-128.

Dae-Hee, A., Won-Seok, C., \& Tai-Il, Y. (1999). Dyestuff wastewater treatment using chemical oxidation, physical adsorption and fixed bed biofilm process. Process Chemistry, (34):429439.

Dhira, A., Sharmab, S., Sudc, D., Ram, C. (2012) Studies on decolourization and COD reduction of dye effluent using advanced oxidation processes, Chemical Engineering, 53, 1198311987.

Endrinaldi. (2010). Logam-logam berat pencemar lingkungan dan efek terhadap manusia. Kesehatan Masyarakat, (4):42-46.

Estikarini, H. D., Mochtar H., Veni L. 2016. Penurunan Kadar COD dan TSS pada Limbah Tekstil dengan Metode Ozonasi. Jurnal Teknik Lingkungan, 1(5):1-11

Gubernur Yogyakarta. (2016). Peraturan Gubernur Daerah Istimewa Yogyakarta No 7 Tahun 2016 Tentang Baku Mutu Limbah Cair Bagi Kegiatan Industri, Pelayanan Kesehatan dan Jasa Pariwisata. Yogyakarta: Sekretaris Daerah.

Hartati, E., Sutisna, M., \& Nursandi, W. (2008). Perbaikan Kuliatas Air Limbah Industri Farmasi menggunakan Koagulan Biji Kelor (Moringa oleifera Lam) dan Poly Alumunium Chloride. Teknologi Lingkungan, 4(3), 73.

Karaouglu, M. H. dan Ulgurlu, M. (2010) Studies on UV/NaOCl/TiO2/Sep photocatalysed degradation of treeactive red 195, Journal of Hazardous Materials, 174, 864-871. 
Kurniawan, M., Purwanto, P., \& Sudarso, S. (2013). Strategi Pengelolaan Air Limbah Sentra UMKM Batik yang Berkelanjutan di Kabupaten Sukoharjo. Jurnal Ilmu Lingkungan, 11(2), 62-72.

Lalwani, P. K., \& Devadasan, M. D. (2013). Reduction Of Cod And Bod By Oxidation: A Cetp Case Study. International Journal of Engineering Research and Applications (IJERA) ISSN: 2248-9622, 3(3), 108-112.

Muhammad, S., Supraptiningsih, S., \& Pradana, A. W. (2013). Penurunan COD Air Limbah Industri Penyamakan Kulit menggunakan Reagen Fenton. Majalah kulit, karet, dan plastik, 29(1), 31-36.

Muljadi. (2009). Efisiensi Instalasi Pengolahan Limbah Cair Industri Batik Cetah dengan Metode Fisika Kimia dan Biologi Terhadap Penurunan Parameter Pencemar (BOD, COD dan Logam Berat Krom). Ekuilibrium, 8(1), 7-16.

Rahardjo, P. N. (2012) Teknologi Pengolahan Limbah Cair dengan Proses Kimia, Pusat Pengkajian dan Penerapan Teknologi Lingkungan BPPT, Jakarta.

Rana, S. dan Suresh, S. (2017) Comparison of different coagulants for reduction of COD from textile industry wastewater, 5 th International Conference of Materials Processing and Characterization, India, 12-13 Maret, 567-576.

Ratnawati, Yoshi, L. A., \& Wibowo, S. A. (2017). Pengaruh $\mathrm{pH}$ dan Dosis $\mathrm{NaOCl}$ terhadap Penurunan Kadar COD dan Klor Bebas pada Limbah Cair Produksi Monomer Vinyl Klorida. Rekayasa Kimia dan Lingkungan, 13(2), 120-126.

Said, M. (2009) Pengolahan air limbah laboratorium dengan menggunakan koagulan alum sulfat dan poli aluminium klorida (PAC), Jurnal Penelitian Sains, edisi khusus Desember, 38-43

Tosik, R., Józwiak, A., Mitros, M. (2004) Application of oxidation process with the use of $\mathrm{H} 2 \mathrm{O} 2$ and $\mathrm{NaClO}$ to dyes aqueous solutions. Annales Universitatis mariaecurie, Skledowska, Lublin, Polonia, LIX 6, 58-66.

Zou, J., Peng, X., Li, M., Xiong, Y., Wang, B., Dong, F., Wang, B. (2017)
Electrochemical oxidation of COD from real textile waste waters: kinetic study and energy consumption, Chemosphere, 171, 322-228. 